\title{
温暖地に建つ学校建築における階段室型自然換気チムニーが 冬期の屋内熱環境に及ぼす影響 \\ THERMAL ENVIRONMENT IN A SCHOOL BUILDING WITH NATURAL VENTILATION CHIMNEY USING STAIRCASE IN WINTER
}

\author{
坂口武司 ${ }^{* 1}$, 山中俊夫*2，甲谷寿史 ${ }^{* 3}$ ，桃井良尚*4 \\ 相良和伸 ${ }^{* 5}$, 張成 ${ }^{* 6}$ \\ Takeshi SAKAGUCHI, Toshio YAMANAKA, Hisashi KOTANI, \\ Yoshihisa MOMOI, Kazunobu SAGARA and Zhang CHENG
}

\begin{abstract}
Recently, as increase of eco-awareness, the number of building adopted with natural ventilation is increasing. Naturally ventilated building is expected to effectively reduce the building's cooling load, and also expected to make people feel comfortable and familiar with nature, especially in spring and autumn. Few studies are found about the actual thermal condition of naturally ventilated building in winter. The purpose of this study is to figure out the influence of the ventilation chimney using staircase on the actual thermal environment and occupants' evaluations in winter. The result shows that closing the opening at the top of chimney decreases the air change rate at room. It is also found that the cold draft at the window side and air leakage through the switched-off ventilation fan also influence on the thermal environment, except for that of ventilation chimney.
\end{abstract}

Keywords : Natural Ventilation, Staircase, Chimney, Winter, Thermal Environment, Occupants'Evaluation 自然換気，階段室，チムニー，冬期，熱環境，居住者評価

\section{1.はじめに}

屋内の快適性向上と、地球環境問題を背景にした自然エネルギー の有効利用の観点から、自然換気システムを積極的に導入した建物 が増えている。特に中間期の積極的な自然換気利用は、涼風の心地 よさと同時に空調負荷低減による省エネルギー効果を期待できる。 学校建築については、文部科学省で環境を考慮した学校施設 (エコ スクール)の整備推進を行っており、その手法の 1 つとして自然換 気システムがあげられている11。

なかでも近年、自然換気チムニーを設け、煙突効果と外部風によ る誘引効果を利用して屋内空気を排出する自然換気システムの導入 事例が増えている。小松ら ${ }^{2)}$ が、建物自身の剥離気流によるチムニ 一上部の風圧と、屋内発熱による温度差の両者を駆動力とした自然 換気に関して、阪神間の大学校舎を対象に風洞実験及び換気計算に

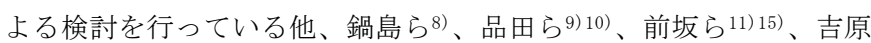
$ら^{13)}$ 、樋渡ら ${ }^{14)}$ が、中間期を中心に自然換気の種々の検討を行って いる。一般的に自然換気建物は中間期の省エネ効果を目的に作られ る一方で、開口部の増大による漏気等が原因となり冬期の熱環境悪 化および暖房負荷増大が懸念されるにもかかわらず、冬期の屋内熱 環境の実態はあまり明らかにされておらず、前坂ら $\left.{ }^{12}\right)$ は大学校舎を 、阿部ら ${ }^{14)}$ は中学校校舎を対象に自然換気性状の計測と評価を行っ ているが、開放型チムニーを有する建物の屋内熱環境および居住者 評価に関する研究は少ない。本研究は、中間期の自然換気を重視して
設計された建物 (設計者=著者: 坂口武司)における、自然換気を行わ ない冬期の屋内熱環境を主題とし、屋上の安定した負圧を利用した 階段室型チムニーを有する学校建築(3)を対象とする。チムニー上部 の開口部 (以下チムニー開口部) が常時開放状態だった 2009 年 1,2 月 の調査と、2013年2月のチムニー開口部への開閉式鋼製扉設置を機 に実施した、チムニー開口部の開放時と閉鎖時の調查を通じて、階 段室型自然換気チムニーが冬期の屋内熱環境に及ぼす影響について 明らかにするものである。現地調査として、熱環境の測定と居住者 評価調查を行い、トレーサガス法により室の換気回数を測定した。

\section{2. 研究方法}

\section{1 調査対象建物とその自然換気システム}

香川県高松市内の大学校舎を調査対象とした。図1に平面図を、図 2 に全景写真をそれぞれ示す。 $\mathrm{RC}$ 造4階建て中廊下型校舎で、1階に 講義室、2,3階に研究室、4階に音楽教室等の実習室が配置されて いる。東西の階段室型チムニーを利用した自然換気システムを採用 しており、中間期に自然換気を積極的に利用し、新鮮な外気を取り 入れる心地よさを居住者が体感すると同時に、外気を効率的に屋内 に導くことにより空調機の使用を抑え、省エネルギー効果を期待し た校舎である。自然換気システムの概要を図 $3 \sim 5 に$ 示す。(1)各室の 空から外気を採り入れ、(2)廊下側の扉と欄間から廊下へ排気、(3)廊 下から階段室を経て屋上のチムニー開口部（ガラリ）から屋外へ排気
*1 竹中工務店設計部

大阪大学大学院工学研究科地球総合工学専攻 博士後期課程

2 大阪大学大学院工学研究科地球総合工学専攻 教授・博士 (工学)

3 大阪大学大学院工学研究科地球総合工学専攻 准教授. 博士 (工学) 大阪大学大学院工学研究科地球総合工学専攻

5 助教 $\cdot$ 博士 (工学) 教授. 工博

*6 大阪大学大学院工学研究科地球総合工学専攻 博士前期課程
Design Department, Takenaka Corporation

Graduate Student, Division of Global Architecture, Graduate School of Engineering, Osaka University, M. Eng.

Prof., Division of Global Architecture, Graduate School of Engineering, Osaka University, Dr. Eng.

Assoc. Prof., Division of Global Architecture, Graduate School of Engineering, Osaka University, Dr. Eng.

Assistant Prof., Division of Global Architecture, Graduate School of Engineering, Osaka University, Dr. Eng.

Prof., Division of Global Architecture, Graduate School of Engineering, Osaka University, Dr. Eng.

Graduate Student, Division of Global Architecture, Graduate School of Engineering, Osaka University 
される仕組みである。階段室を換気経路として利用し、煙突効果に より無風時でも換気が促進される仕組みである。なお、1,4階は講 義や実習に伴う防音上の理由から、室と廊下を仕切る扉は閉鎖状態 で運用されることを想定して計画されており、前述の自然換気シス テムは2,3階の研究室を対象としている。
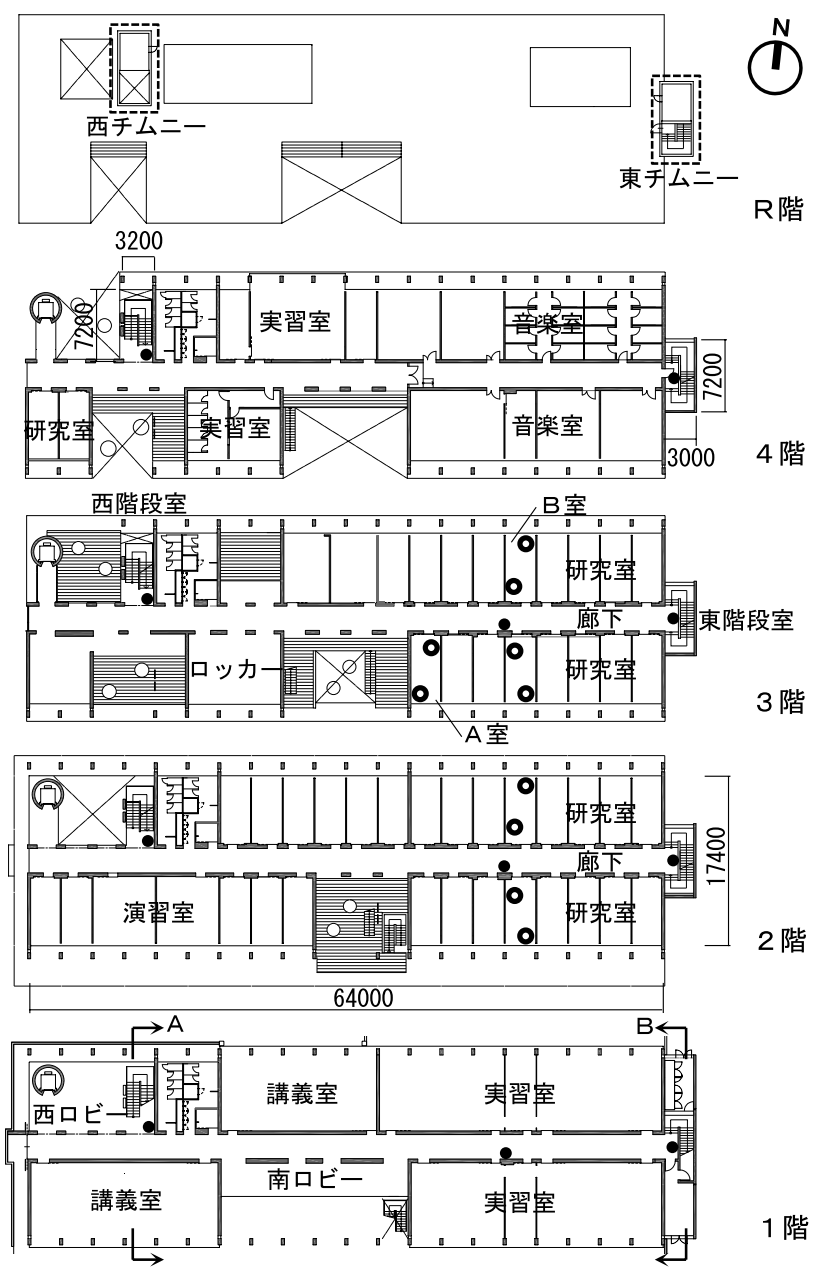

- 研究室内測定点 $(F L+100,600,1100,1700,2200)$ ・廊下 ・ 階段測定点 $(F L+1100)$

図 1 平面図 : 東西に階段室型チムニーを有する中廊下型プラン (単位mm) Scale 1:1000

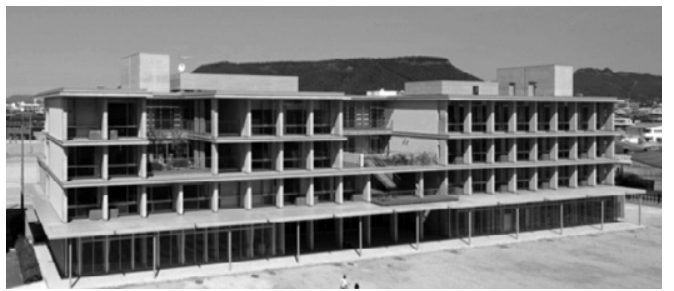

図 2 南西からの全景写真 : 校舎東西屋上に突出するチムニー 外装ガラスはシングルガラス $\mathrm{t} 6$ または $8 \mathrm{~mm}$

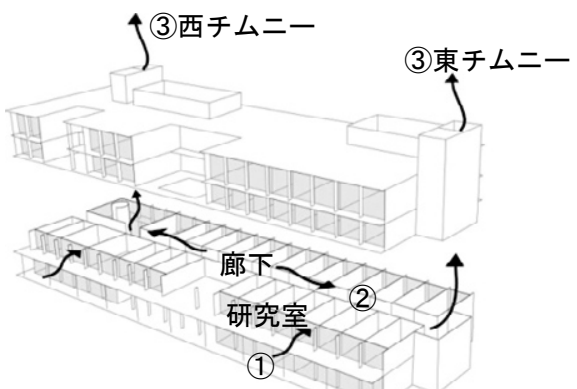

図 3 自然換気システムの全体概要
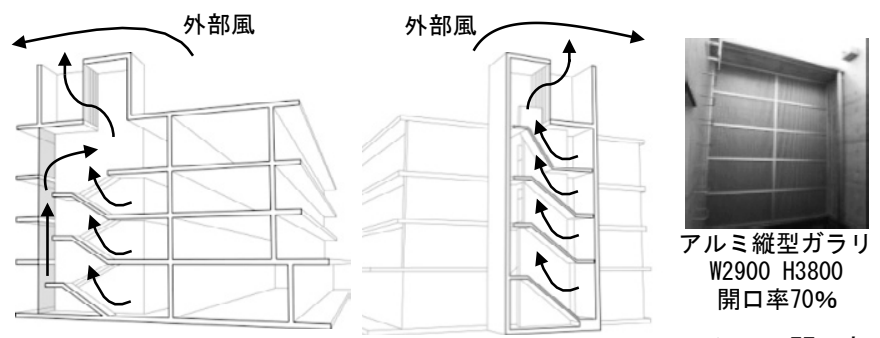

西階段室 (図 1 A 断面)

東階段室 (図 $1 \mathrm{~B}$ 断面) チムニ一開口部

図4 階段室断面模式図 : 煙突効果と誘因効果による換気促進

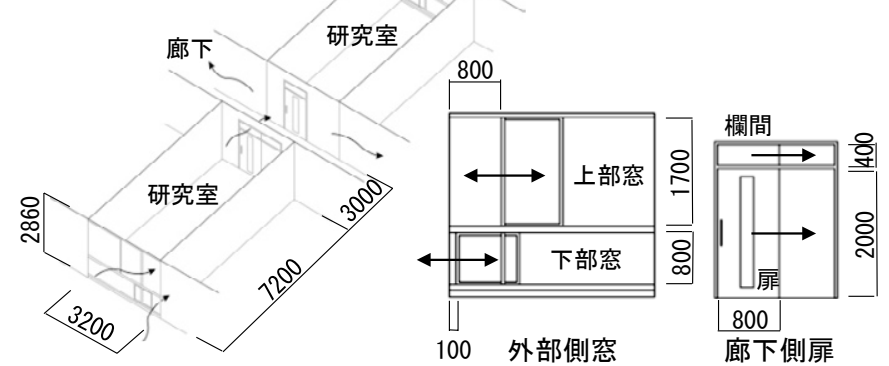

図 5 研究室に外気を採り入れ廊下へ排気する通風ルート (単位: $\mathrm{mm}$ )

\section{2 チムニ一開口部、開放・閉鎖用鋼製扉と鋼製板}

2013年2月に設置した鋼製扉の概要を図6に示す。西階段室にはチ ムニ一開口部の屋外側に鋼製扉を設置、東階段室には、チムニー開 口部に至る経路上に鋼製扉を設置し、踊場床と壁面との間の通気ス リットには鋼製板(着脱式パネル)を設置している。
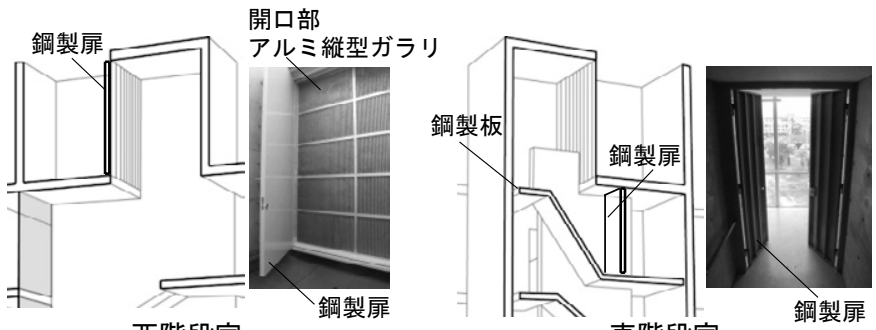

図 6 開閉式鋼製扉

\section{3 調査 $\cdot$ 検討内容}

本研究で報告する調查・解析項目を表 1 に示す。

（1）熱環境調查：校舎内各所の温度測定を行った。

（2）居住者評価調査：教員と学生を対象にアンケート調査を行った。

(3) 換気回数測定 : 単室の研究室において $\mathrm{CO}_{2}$ をトレーサガスとして 濃度減衰多時点法で換気回数を測定した。

表 1 調查・検討項目

\begin{tabular}{|c|c|c|c|}
\hline \multirow[b]{2}{*}{ 実施期間 } & 1 年目調査: 2009 年 (3章) & \multicolumn{2}{|c|}{ 閉鎖装置設置後調査：2013年 (4章) } \\
\hline & $\begin{array}{c}1 / 26 \sim 2 / 6 \\
12 \text { 日間 }\end{array}$ & $\begin{array}{c}2 / 3 \sim 2 / 6 \\
4 \text { 日間 }\end{array}$ & $\begin{array}{c}\text { 2/7 2/17 } \\
\text { 11日間 }\end{array}$ \\
\hline \multirow{2}{*}{ 調査の位置付け } & 竣工1年目調査 & \multicolumn{2}{|c|}{ 冬期居住環境の改善検討用調査 } \\
\hline & 問題点の把握 & \multicolumn{2}{|c|}{ ドラフト、換気量の詳細把握 } \\
\hline チムニー開口部 & 開放 & 開放 & 閉鎖 \\
\hline 建物各所温度 & 0 & 0 & 0 \\
\hline 上下温度分布 & $\bigcirc$ & 0 & 0 \\
\hline 居住者評価調査 & 平日10日 & 平日3日 & 平日6日 \\
\hline 換気回数測定 & - & $2 / 3$ & $2 / 9$ \\
\hline
\end{tabular}




\section{3. 竣工 1 年目の調査}

\section{1 熱環境調査}

\section{1.1 調査手法}

小型温度計 (T\&D社製，TR72U，TR71S) を、廊下と階段室において 床から高さ $1100 \mathrm{~mm}$ の位置に、2,3階研究室内において床から高さ $100 \mathrm{~mm}, 600 \mathrm{~mm}, 1100 \mathrm{~mm}, 1700 \mathrm{~mm}, 2200 \mathrm{~mm}$ の位置にそれぞれ設置した。測 定機器の設置位置は図1に示す。

\section{1.2 調査結果と考察}

図 7,8 に階A室の測定点と鈶直温度分布を示す。A室は南空側がフ ルワイドかつフルハイトの大型シングルガラス空で、空側にエアコ ンが設置されている。なお、空横の 24 時間換気扇には外気流入防止 ダンパーは備わっていない。計測点はエアコンの気流や日射の影響 の少ない廊下側とした。各プロットは、各日 12 時の温度データで あり、䁔房不使用日として $2 / 1$ の結果を、暖房使用日として $1 / 28,2 / 2,2 / 3$ の結果を示す。暖房使用時には床上高さ $100 \mathrm{~mm}$ (足元を想 定) と $1100 \mathrm{~mm}$ (着席時頭部を想定) とでは $3 \sim 5^{\circ} \mathrm{C}$ 程度の温度差が見ら れるが、暖房不使用の $2 / 1$ には上下温度差がほとんど見られない。 また、床上 $100 \mathrm{~mm}$ での温度は暖房使用、非使用を問わず $14 \sim 16^{\circ} \mathrm{C} て ゙$ ほぼ一定であり、暖房を使用しても足元の温度が上がっていないこ とを示している。

図9に外気温と東西階段室温度との関係、図10に外気温と廊下温 度との関係を示す。戝9 10 を比較すると、階段室は廊下よりも温 度が低く、外気温とほぼ等しい時間帯も存在する。廊下は、3、4階 の温度が 1 、2 階よりも高くなっており、1階出入口の影響や暖かい 空気が上昇するためと考えられる。階段室型チムニーの上部開口部 が開放状態のため、階段室に外気が流入していると推測される。
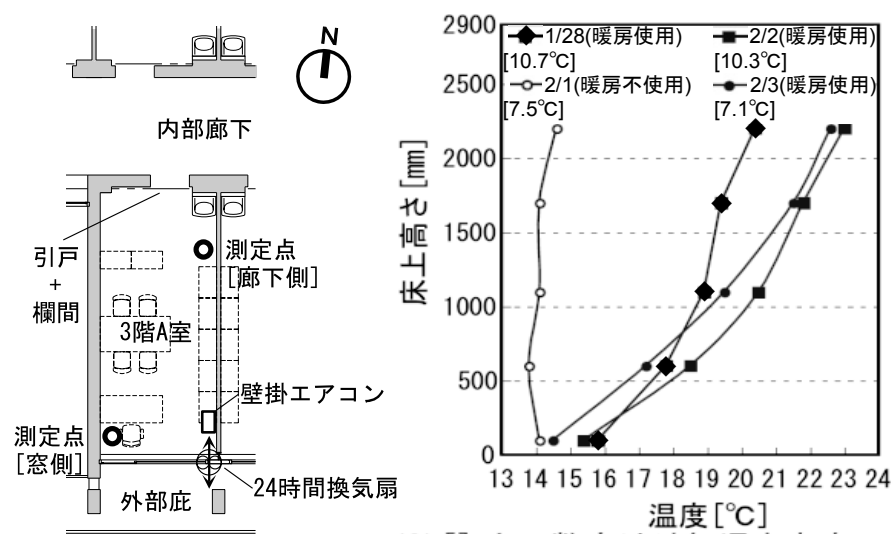

図 7 測定点平面図 (3階A室)

※[] 内の数字は外気温を表す。

図 8 開放時 鉛直温度分布 (各日12時)

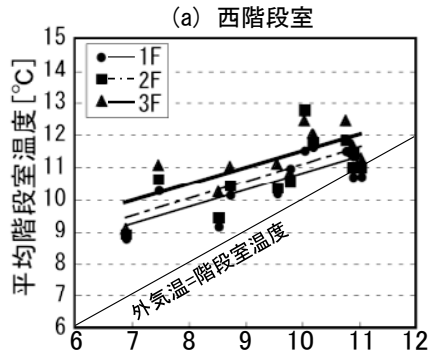

平均外気温 $\left[{ }^{\circ} \mathrm{C}\right]$



平均外気温 $\left[{ }^{\circ} \mathrm{C}\right]$
図 9 チムニ一開放時 外気温と階段室温度の関係 (1/26 2/6、各日 9 12 時平均値)

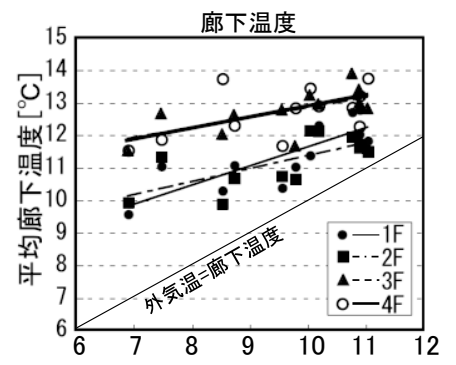

図 10 チムニー開放時 外気温と廊下温度の関係 (1/26 2/6、各日 $9 \sim 12$ 時平均值)

\section{2 居住者評価調査}

\section{2.1 調査手法}

2, 3階の研究室を利用する教員と学生を対象に、温冷感に関する アンケート調査を行った。実施期間とチムニー開口部の開閉状態を 表 1 に示す。アンケートは2種類で、1 つはアンケート用紙の冒頭 に「冬を対象として総合的にお答えください」と明記した、冬期 全般の空開閉状況や温冷感に関するアンケートで、期間中 1 回回 答してもらった (以下「1回」)。もう 1 つは日々の空開閉状況や温 冷感を中心に居住者評価を把握するため調査期間を通じて毎日回 答してもらった(以下「毎日」)。アンケート項目を表 2 に示す。

$$
\text { 表 } 2 \text { アンケート項目 }
$$

\begin{tabular}{|c|c|}
\hline \multicolumn{2}{|c|}{ 1回アンケート } \\
\hline 1. 個人属性 & $\begin{array}{l}\text { 性別、年齢、教員学生区分、省エネ関心度、 } \\
\text { 暑がり解度 }\end{array}$ \\
\hline 2. 居室について & 室番号、在室人数、発熱機器数 \\
\hline 3. 暖房空調について & $\begin{array}{l}\text { 使用器具、使用時間、在室時間に対する使用時間割合 } \\
\text { 没定温度、拃をう主呠 }\end{array}$ \\
\hline 4. 24時間換気扇について & 使用頻度、使用理由、使用しない理由 \\
\hline 5. 自然換気について & 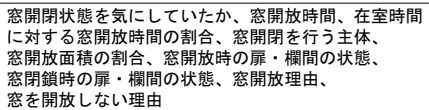 \\
\hline 6. 温熱・空気環境について & $\begin{array}{l}\text { 暖房未使用時の温冷感、暖房使用時の温冷感， } \\
\text { 上下温度差、廊下、階段の温冷感、冬に対象建物を } \\
\text { 使用する際に気になな点 }\end{array}$ \\
\hline \multicolumn{2}{|c|}{ 毎日アンケート } \\
\hline 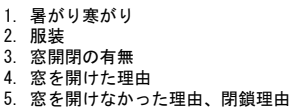 & $\begin{array}{l}\text { 6. 暖房使用時間 } \\
\text { 7. 暖房不使用時の温冷感 } \\
\text { 8. 暖房使用時の温泠感 } \\
\text { 9. 暖房使用時の上温度差感 } \\
\text { 10. 温熱・空気環境にこついて不快なこと }\end{array}$ \\
\hline
\end{tabular}

\section{2.2 調査結果と考察}

図11に、暖房使用時、暖房不使用時の研究室内温冷感についての回 答結果を示す。暖房使用時の「寒い」「涼しい」の回答者は男性7\%、 女性15\%、暖房不使用時は男性75\%、女性81\%であり、暖房使用によ り寒さ感が緩和される評価となった。「寒い」に着目すると、男性は 暖房使用時 $0 \%$ 、不使用時 $54 \%$ 、女性は使用時 $11 \%$ 、不使用時 $78 \%$ であり、 女性のほうが寒さを感じやすい傾向にあることを示す結果となった。
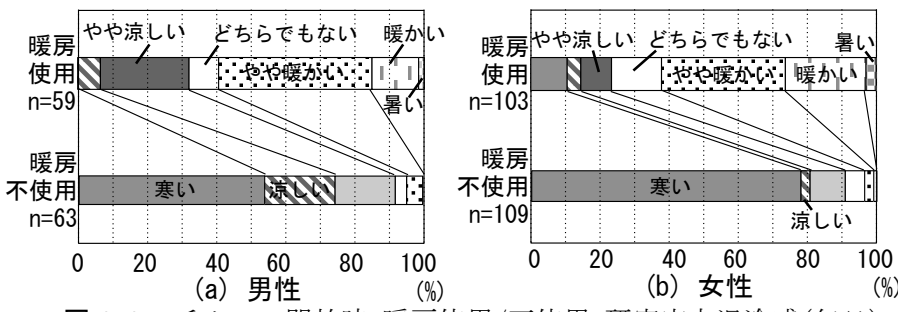

図 11 チムニ一開放時 暖房使用/不使用 研究室内温冷感 (毎日)

図12 (a)に上下温度差感に関する回答結果を示す。「感じない」は13 \%で、温度差を感じるとの回答が $87 \%$ ある。図 8 の鉛直温度分布の グラフから、足元 (床面から $100 \mathrm{~mm}$ ) と着席状態での頭部 (同 $1100 \mathrm{~mm}$ ) とでは、暖房使用時には $3 \sim 5^{\circ} \mathrm{C}$ 温度差があることがわかる。 
図12 (b) に廊下・階段室の温冷感に関する回答結果を示す。「寒い

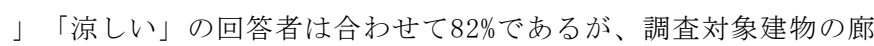
下と階段室は非空調で、チムニー開口部開放時は、ほぼ外部と同じ 熱環境であると予想される。図9,10からも廊下と階段室の温度はほ ぼ外気温と等しいことが読み取れる。

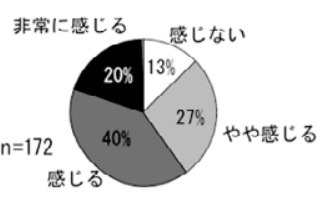

(a) 上下温度差感 (毎日)
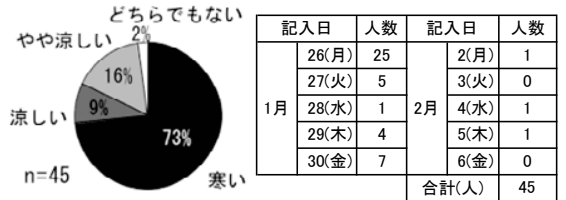

(b) 廊下・階段室温冷感 ( 1 回 $)$
図 12 チムニー開放時 アンケート結果

\section{3 本章のまとめ}

1 年目調查 (2009年冬期実施、チムニー開口部開放)の、における 調査の結果、以下の2点が実態として明らかになった。

1）研究室内で、足元と上半身の高さとでは暖房使用時で約 $5^{\circ} \mathrm{C} の$ 温度差があり、アンケート結果から温度差を感じている人が 80 \%以上で、「足元の冷え」が気になる点として多くあげられた。

2）階段室温度は外気温とほぼ等しく、気になる点でも「足元の 冷え」に次いで「廊下・階段の熱環境」の回答が多かった

これらの原因が、大型ガラス空によるコールドドラフト、冬期に おいても開放状態のチムニー開口部、24時間換気扇からの空気の出 入りにあると推測し、ひとつの可能性として検討するためにチムニ 一開口部に閉鎖装置を設置し、4 章の設置後調查を実施した。

\section{4. チムニー開口部閉鎖装置設置後の調査}

\section{1 熱環境調査}

\section{1.1 調査手法}

1年目調査 ( 3.1 .1 に示す) と同じ手法を用いた。

\section{1.2 調査結果と考察}

(1) 調查期間中の気象条件と建物内温度変化

図13に調查期間中の外気温、建物内3階各所の温度、全天日射量 を示す。建物内温度の測定は、図1に示す位置で床から高さ $1100 \mathrm{~mm}$ にて行った。研究室の温度変化から、チムニー開口部開放の 2 月 4 6 日、同閉鎖の 2 月 $7,8,12$ 15日に暖房運転を行ったことが分か るが、外気温変化からは、開放時に比べ閉鎖時の方が外気温が低 めに推移していたことが分かる。図14に外部風向と風速を示寸。 西方向からの風の出現頻度が高いことが分かる。 温度 $\left({ }^{\circ} \mathrm{C}\right)$

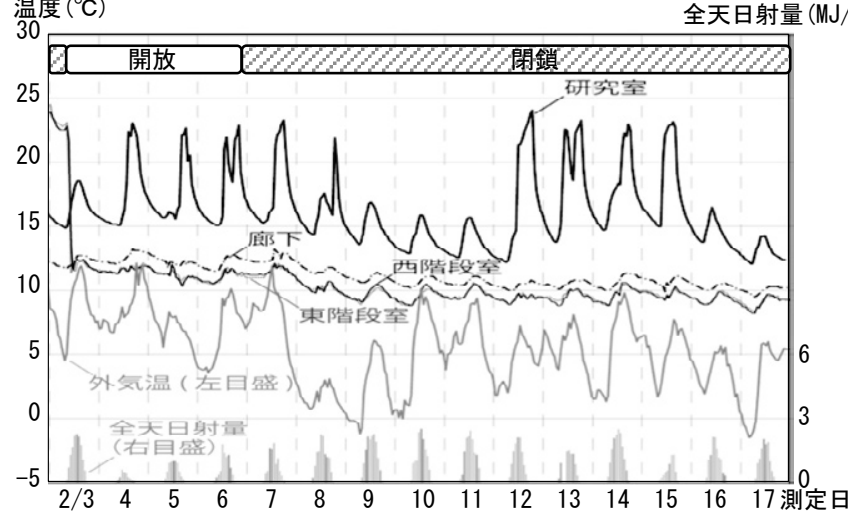

図 13 3階廊下温度、同東西階段室と研究室 (A室廊下側) 温度 外気温(アメダス高松)、全天日射量(同左)



風速

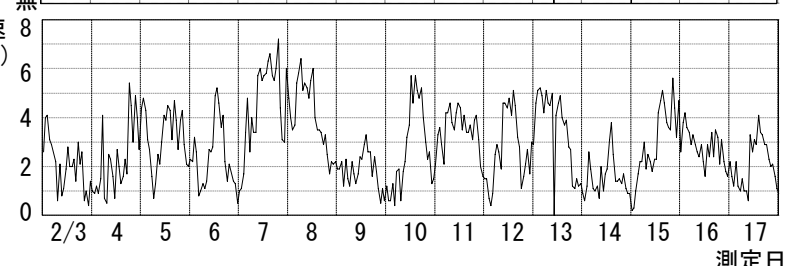

図 14 外部風向と風速 (アメダス高松)

（2）廊下の温度変化

図15にチムニー開口部が開放状態の $2 / 5,6$ 、閉鎖状態の $2 / 14,15$ の 廊下温度変化を示す。開放時は $10 \sim 13{ }^{\circ} \mathrm{C}$ 、閉鎖時は $9 \sim 12{ }^{\circ} \mathrm{C}$ で推 移し、いずれも外気温にあまり左右されない。開放状態の $2 / 5$ の 9:00 18:00において、廊下温度の上下変動が見られ、外気が流入 していると思われる。このような上下変動は閉鎖時には見られない。
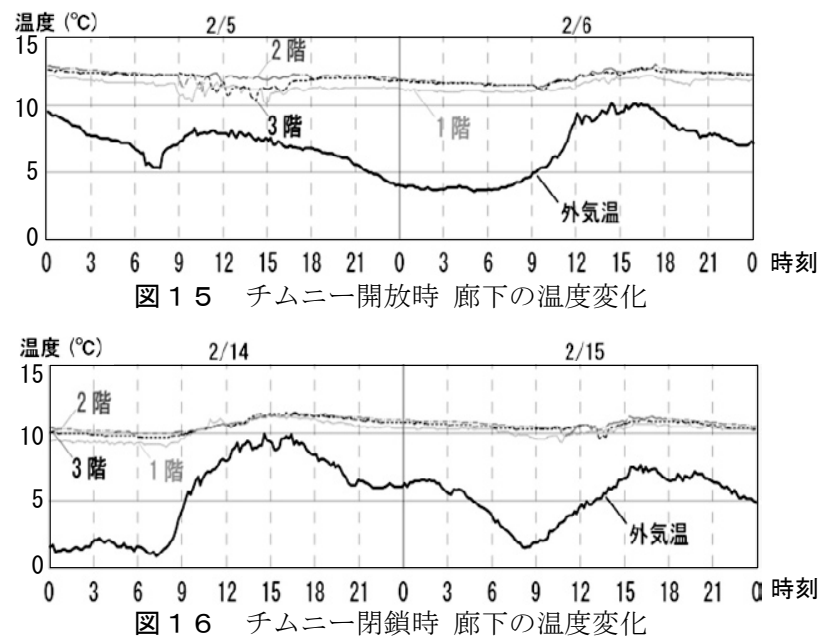

（3）外気温と廊下・階段室温度の関係

図17,18に外気温と3階廊下・階段室温度の関係を示す。チムニー

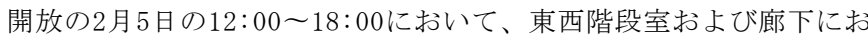
いて、温度が低下し外気温との温度が差が小さくなることが確認さ れた。12:00の温度に着目すると、廊下においてまず低下し始め、 遅れて西階段室が低下し、いずれも $1.5^{\circ} \mathrm{C}$ 程度の低下である。東階 段室においても低下の現象が見られるが、0. $5^{\circ} \mathrm{C}$ 程度の低下である。 図14に示寸通り同時間帯には風速 $4 \mathrm{~m} / \mathrm{s}$ 前後の東風が継続的には発生 しており、東側チムニーで誘因効果が高まり、西側1階ロビーや研 究室等から外気が流入することにより、西側階段室温度および廊下 温度が低下し、主に東階段室経由で東側チムニー開口部から排気さ れたものと推測される。一方、チムニー閉鎖時には、この現象は確 認できなかった。

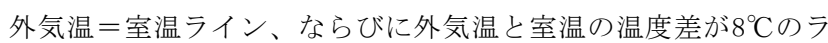
インとの関係に着目すると、チムニー開放の 2 月 4 日の $18: 00$ 前後、 東西階段室において室温が外気温をわずかに下回る時間帯が確認さ れた。廊下温度も同時間帯に外気温近くまで低下しており、自然換 気量が大きいことが予想される。これも、チムニー閉鎖時には確認 できなかった。 


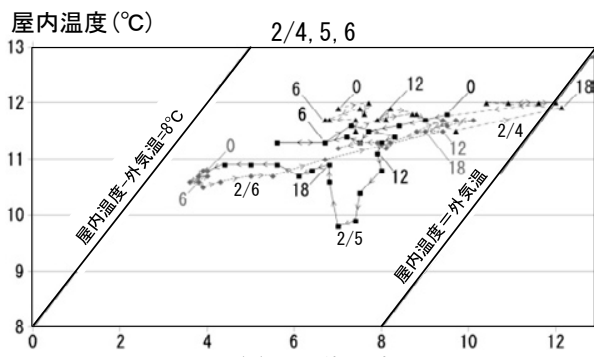

(a) 西階段室

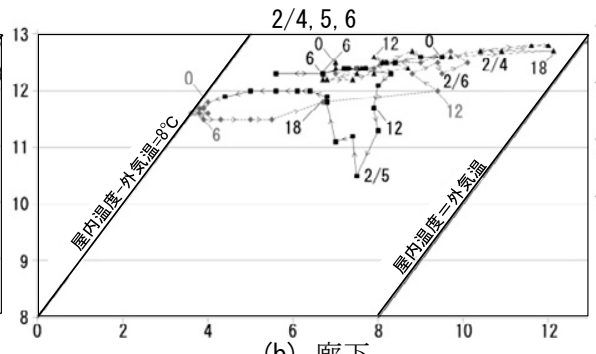

(b) 廊下 $^{8}$

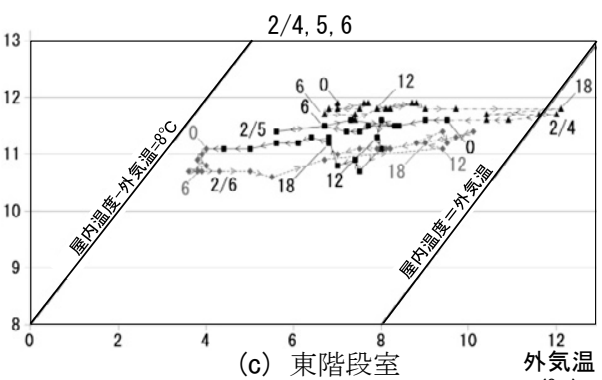

(c) ${ }^{6}$ 東階段室 ${ }^{8}$ 外気温

図 17 チムニー開放時 $(2 / 4,5,6)$ 外気温と 3 階屋内温度の関係の経時変化（図中引出線で示す $0,6,12,18$ は測定時刻を示す）
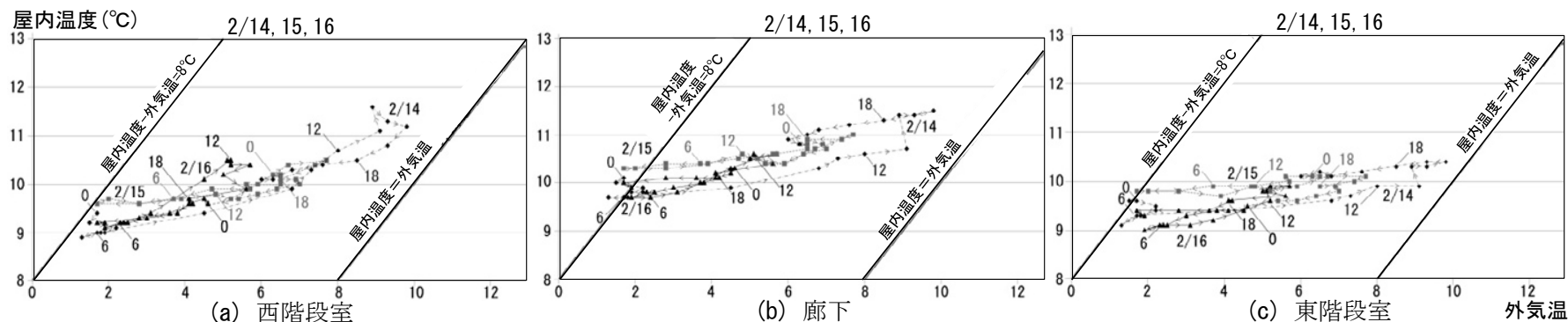

図 18 チムニー閉鎖時 $(2 / 14,15,16)$ 外気温と 3 階温度の関係の経時変化（同上）

(c) 東階段室

\section{(4) 研究室内の温度変化}

図7に3階A室における計測点を示す。南面する窓近くにエアコン があり、執務机はこの窓近くに配置されている。図19にチムニー開放 の $2 / 5,6$ 、閉鎖の $2 / 14,15$ の階A室の温度変化を示す。計測点は図 7 に示す。昼間に暖房を入れていた研究室の夜間の温度変化を見ると 、廊下側は暖房停止後速やかに上下温度差が小さくなり $1^{\circ} \mathrm{C}$ 未満に なる一方、空側は温度差が $2 \sim 3{ }^{\circ} \mathrm{C}$ のまま翌朝まで推移する。床から 天井までの大型空ガラスのため、空際でコールドドラフト現象が発 生し、廊下側より空側で上下温度差が大きくなると考えられる。こ の傾向は、チムニー開口部の開放閉鎖を問わず確認された。

\section{(5) 研究室内の上下温度分布}

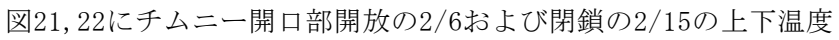
分布を示す。0:00および6:00〜 18:00の2時間毎の瞬時值を示し、外 気温は高松アメダス観測データを用いた。図19,20の温度変化から、 2/6は12:00頃から 21:00頃まで、2/15は12:00頃から 18:00頃まで暖 房を使用したと考えられる。

床上 $100 \mathrm{~mm}$ と $1100 \mathrm{~mm}$ との温度差は、暖房時には、開放、閉鎖とも最 大 $6 \sim 7{ }^{\circ} \mathrm{C}$ で、暖房不使用時には、開放、閉鎖とも上下温度差がほと んど見られなかった。「3．1 熱環境調查」に示寸2009年の調査 結果では、開放時の暖房時に $5{ }^{\circ} \mathrm{C}$ 程度の温度差が生じていること、 暖房不使用時は上下温度差がほとんどないことを確認したが、同様 の現象が2013年の調査でも確認された。床上 $100 \mathrm{~mm}$ の温度は、2009 年も計測した廊下側では、暖房使用時、非使用時とも、また開放、 閉鎖とも $15 \sim 16{ }^{\circ} \mathrm{C}$ で一定しており、暖房を使用しても温度がほとん ど上昇しておらず、これも2009年の調査結果と一致した傾向を示 した。一方、空側では開放時は $13 \sim 18^{\circ} \mathrm{C}$ 、閉鎖時は $14 \sim 19^{\circ} \mathrm{C}$ と変化 を示している。夜間から朝方にかけては、廊下側よりも温度が低下 しており、大型ガラス公によるコールドドラフトによる温度低下と 推測される。一方、昼間の暖房使用時には廊下側よりも上昇して おり、暖房の気流と日射の影響が考えられる。
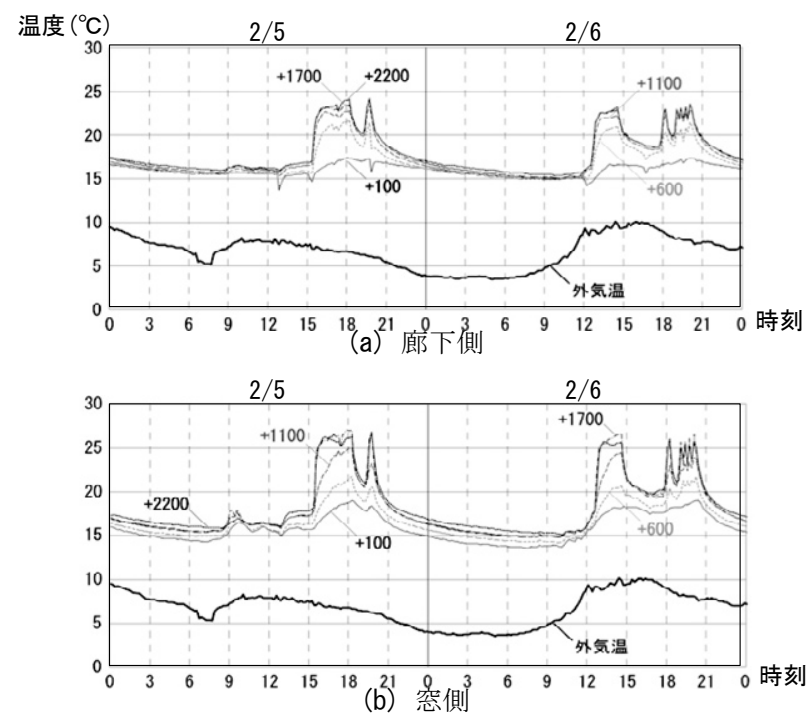

図 19 チムニー開放時 3 階A室の温度変化
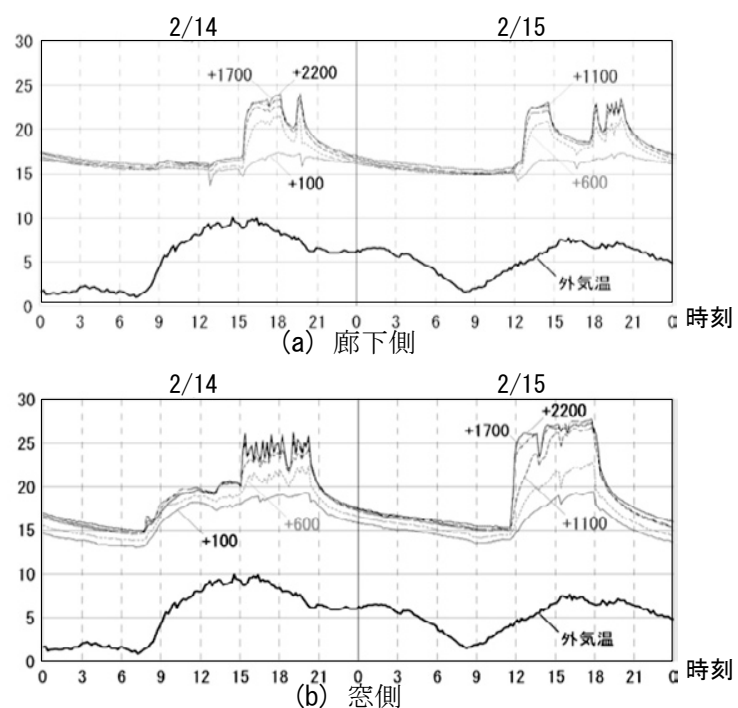

図 20 チムニー閉鎖時 3 階A室の温度変化 


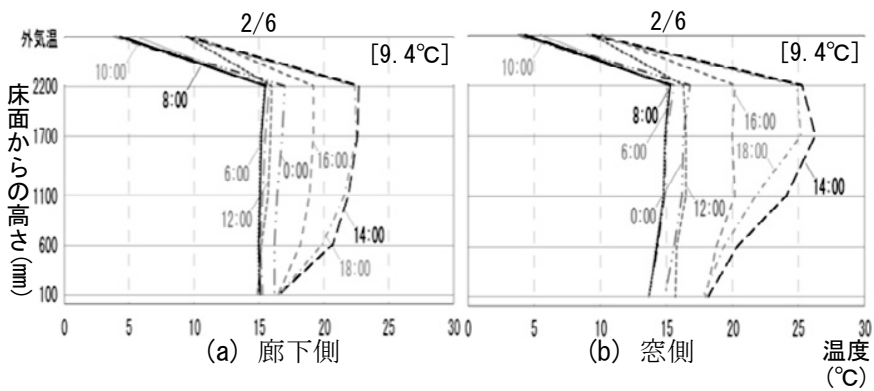

図 21 チムニー開放時 $(2 / 6)$ 上下温度分布 []は当日 12 時の外気温

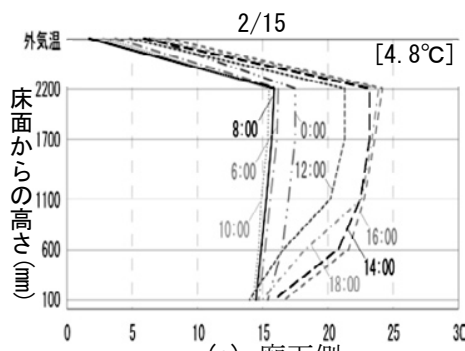

(a) 廊下側

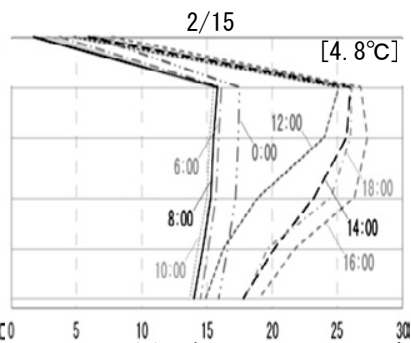

(b) 空側 ${ }^{20}$ 温度
図 22 チムニー閉鎖時 $(2 / 15)$ 上下温度分布 []は当日 12 時の外気温

\section{2 居住者評価調査}

\section{2. 1 調査手法}

1 年目調查 $(3.2 .1$ 参照) と同手法で、 $2 / 4$ (月) 8 (金)、 12 (火) 15 (金) (11は祝日)の 9 日間行った。2/4〜6の3日間はチムニー開口部 が開放、残る6日間は閉鎖で、グラフに[開放］[閉鎖］と記す。

\section{2.2 調査結果と考察}

図23に暖房不使用時の研究室内の温冷感に関する回答結果を示す。 一般的に男性に比べて寒さに敏感とされる女性の回答で、開放時よ りも閉鎖時の方が「寒い」が10ポイント以上少ないが、男性の回答 では逆に「寒い」が多い。
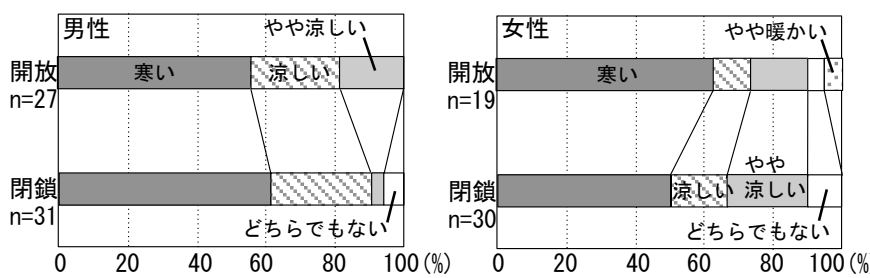

図 23 暖房不使用時の研究室内の温冷感 (左 : 男性、右 : 女性)

図24に暖房使用時の研究室内の温冷感に関する回答結果を示す。女 性の回答で、開放時よりも閉鎖時の方が「寒い」が10ポイント程度 少ないが、男性では逆に「寒い」が10ポイント程度多い結果となっ た。「どちらでもない」「やや暖かい」「暖かい」「暑い」の合計 は、女性の回答で閉鎖時の方がわずかに多い。一方、男性の回答で は逆に開放時の方がわずかに多い。暖房不使用時、使用時とも閉鎖 時の方が、研究室内熱環境が暖かい側の回答が多いと予想したが、 そのような傾向はなかった。開放 3 日間の平均気温（アメダス高松） が $7.5^{\circ} \mathrm{C}$ 、閉鎖6日間の平均気温（同）が $5.1{ }^{\circ} \mathrm{C}$ であり外部温度の違い があったことが一因と推測される。

図25に、暖房使用時の上下温度差感の結果を示す。t検定の結果、 男性は $\mathrm{p}=0.114$ 、女性は $\mathrm{p}=0.0655$ で、統計的に有意とまではいえなか
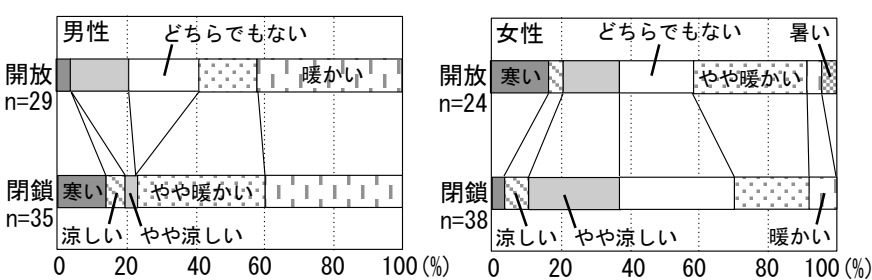

図 24 暖房使用時の研究室内の温冷感 (左 : 男性、右 : 女性)

ったものの、男女ともチムニー閉鎖時は開放時よりも上下温度差感が 緩和される傾向が見られた。これについては、アンケートお願い書に、 チムニー開口部への開閉扉設置が冬期の屋内熱環境改善を目的とする 旨を明記したこと ${ }^{[1]}$ が回答者に心理的効果をもたらしたことが一因で あると推測する。


図 25 暖房使用時の頭・上半身と足元・下半身との温度差感 （左：男性、右：女性）

\section{3 トレーサガスを用いた換気回数測定 ${ }^{4)}$ \\ 4. 3. 1 調查手法}

トレーサガス $\left(\mathrm{CO}_{2}\right)$ を研究室内に発生させ発生停止後の濃度減衰 過程を測定し、研究室の換気回数を算出することにより、各条件に おける研究室の自然換気量を把握した。3階B室 (図1参照)を測定対 象とした。表3、4 測定条件、図26に研究室平面図を示す。ガスモ ニタはT\&D社製RTR-576、マスフローコントローラはAera社製FC-771 を使用した。表3、4 亿示寸減衰時摚汼ON/OFFについて、本換気量測定 法4)では通常擋汼を行うが、実際の使用状況 (擋拌が行われない) とは、濃度分布および温度分布が異なり、実際の使用状況とは異な る換気回数が得られる。一方、擋汼を行わないと濃度分布が生じ、 実際の流量とは異なる結果となる。ゆえに両条件にて換気回数測定 を行い、両方の值でチムニー開口部開閉の効果を検討することと した。24時間換気扇については、冬期の使用実態を踏まえ、「0FF 」を実施した。24時間換気扇には $0 F F$ 時に外気流入を遮断するダン パーが内蔵されていないため、外気流入ルートとなる可能性を想定 した。24時間換気扇を閉鎖すると換気回数が減少すると予測をたて 、ビニルテープにて目貼り閉鎖をし、濃度減衰過程の測定を行った。

表 3 測定条件 (2月 3 日・チムニー開口部開放)

\begin{tabular}{|c|c|c|c|c|c|c|c|c|}
\hline & $\begin{array}{c}\mathrm{CO}_{2} \text { 発生 } \\
\text { 開始 }\end{array}$ & $\begin{array}{c}\mathrm{CO}_{2} \text { 停止 } \\
\text { 減衰開始 }\end{array}$ & $\begin{array}{l}\text { 減衰 } \\
\text { 終了 }\end{array}$ & $\begin{array}{c}\mathrm{CO}_{2} \text { 発生 } \\
\mathrm{C} / \mathrm{min}\end{array}$ & $\begin{array}{c}\text { 発生時 } \\
\text { 擋挥 }\end{array}$ & $\begin{array}{c}\text { 滅喑時持 } \\
\end{array}$ & $\begin{array}{l}\text { エアコン } \\
\text { 設定温度 }\end{array}$ & $\begin{array}{l}\text { 24時間 } \\
\text { 換気扇 }\end{array}$ \\
\hline 1 回目 & $10: 25$ & $10: 50$ & $11: 45$ & 10 & ON & ON & $25^{\circ} \mathrm{C}$ & OFF \\
\hline 回目 & $11: 55$ & 12:09 & $12: 38$ & 10 & ON & $\begin{array}{c}12: 14 \\
\text { OFF }\end{array}$ & $25^{\circ} \mathrm{C}$ & OFF \\
\hline
\end{tabular}

表 4 測定条件 (2月9日・チムニー開口部閉鎖)

\begin{tabular}{|c|c|c|c|c|c|c|c|c|}
\hline & $\begin{array}{c}\mathrm{CO}_{2}^{\text {発生 }} \\
\text { 開始 }\end{array}$ & $\begin{array}{c}\mathrm{CO}_{2} \text { 停止 } \\
\text { 減袁開始 }\end{array}$ & $\begin{array}{l}\text { 減衰 } \\
\text { 終了 }\end{array}$ & $\begin{array}{l}\mathrm{CO}_{2} \text { 発生 } \\
\ell / \mathrm{min}\end{array}$ & $\begin{array}{c}\text { 發生時 } \\
\text { 擋拌 }\end{array}$ & $\begin{array}{c}\text { 滅言晆 } \\
\text { 擋挥 }\end{array}$ & $\begin{array}{l}\text { エアコン } \\
\text { 設定温度 }\end{array}$ & $\begin{array}{l}\text { 24時間 } \\
\text { 換気扇 }\end{array}$ \\
\hline 1 回目 & $10: 20$ & $10: 56$ & $12: 12$ & 10 & ON & ON & $25^{\circ} \mathrm{C}$ & OFF \\
\hline 2 回目 & $12: 13$ & $12: 41$ & $14: 00$ & 10 & ON & OFF & $25^{\circ} \mathrm{C}$ & OFF \\
\hline 3 回目 & $14: 14$ & $14: 31$ & $16: 00$ & 10 & ON & ON & $25^{\circ} \mathrm{C}$ & 閉鎖 \\
\hline
\end{tabular}




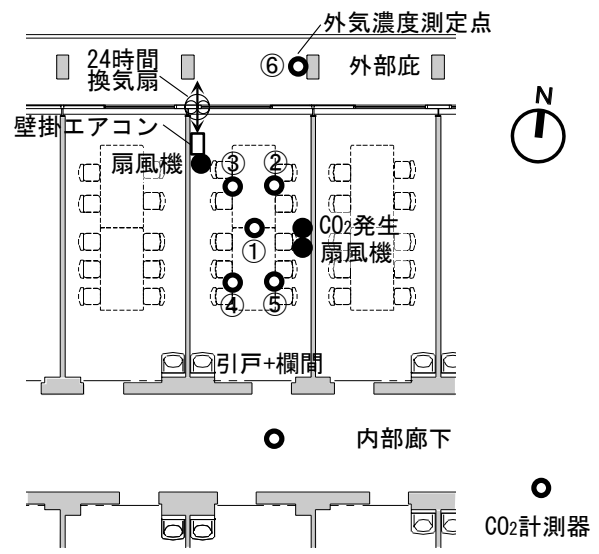

図 26 研究室(3階B室)平面図

\section{3.2 調査結果と考察}

室内濃度分布がほぼ一様であり、かつ測定期間中の換気回数が時 間変化しないことをふまえ、濃度減衰多時点法により下式を用いて 換気回数を求めた。

$$
\begin{aligned}
\log e & \left\{C(t)-C_{0}(t)\right\}=-N\left(t-t_{1}\right)+\log e\left\{C\left(t_{1}\right)-C_{0}\left(t_{1}\right)\right\} \\
t & : \text { 時刻 } \quad[\mathrm{h}] \quad C(t): t \text { における室内濃度 }\left[\mathrm{m}^{3} / \mathrm{m}^{3}\right] \\
t_{1} & : \text { 減衰開始時刻 }[\mathrm{h}] \quad C_{0}(t): t \text { における外気濃度 }\left[\mathrm{m}^{3} / \mathrm{m}^{3}\right] \\
N & : \text { 換気回数 } \quad[1 / \mathrm{h}]
\end{aligned}
$$

図 27 に2月 9 日チムニー開口部閉鎖時の研究室内 5 点外部 1 点の $\mathrm{CO}_{2}$ 濃度測定結果、図28に同日 1 回目減衰時の自然対数濃度と近似直線 を示す。また、表5に計測条件と近似直線から得た換気回数を示す。

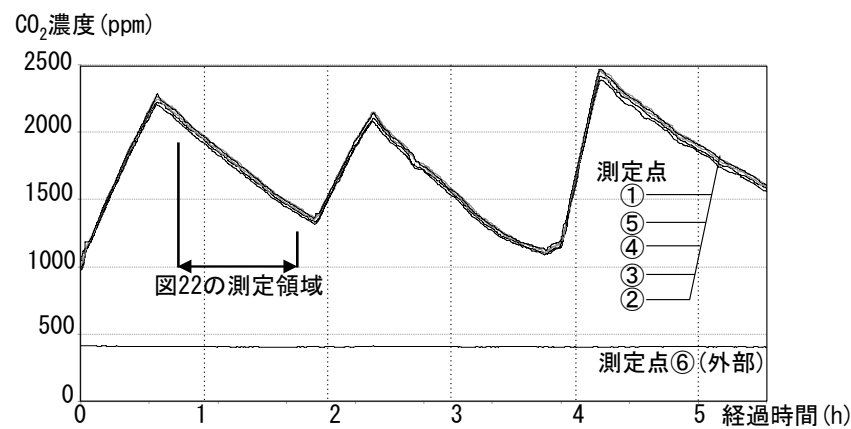

図 27 室内 5 点における $\mathrm{CO}_{2}$ 濃度測定結果 $(2 / 9$ チムニー開口部閉鎖 $)$

\begin{tabular}{|c|c|c|c|c|}
\hline \\
\hline チムニ一開口部 & 計測 & 減衰時擋拌 & 24時間換気扇 & 換気回数 (回/h) \\
\hline \multirow{2}{*}{$\begin{array}{c}\text { 開放 } \\
(2 / 3 \text { 施) }\end{array}$} & 1回目 & ON & OFF & 0.72 \\
\hline & 2回目 & 途中から0FF & OFF & 0.84 \\
\hline \multirow{3}{*}{$\begin{array}{l}\text { 闠 } \\
(2 / 9 \text { 実施) }\end{array}$} & 1回目 & ON & OFF & 0.52 \\
\hline & 2回目 & OFF & OFF & 0.69 \\
\hline & 3回目 & ON & 目貼り閉鎖 & 0.39 \\
\hline
\end{tabular}

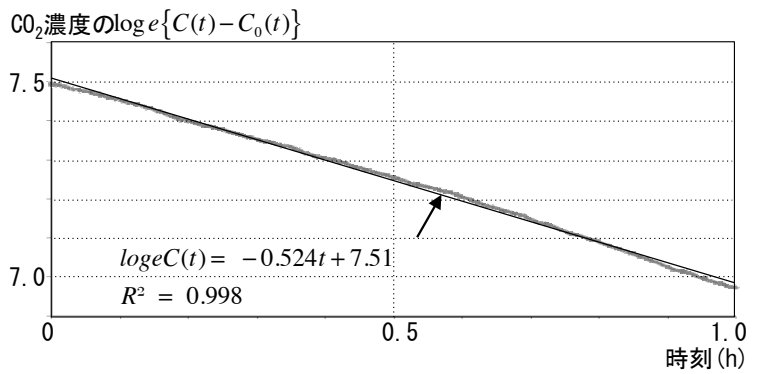

図 28 室内5点平均濃度と外部濃度の差の自然対数濃度

表 5 計測条件と換気回数
日常使用状態に近い室内空気の擋拌を行う条件で、開放時 0.72 回/ $\mathrm{h}$ 、閉鎖時 0.52 回 $/ \mathrm{h}$ の換気回数で、閉鎖状態の方が開放状態よりも 室内空気の出入りが少なかった。擋汼を行わない条件では、開放時 0.84 回 $/ \mathrm{h}$ 、閉鎖時 0.69 回 $/ \mathrm{h}$ と閉鎖状態の方が換気回数が少なかった。

研究室の外壁には24時間換気扇が設置されている。給排気口とも ファンが内蔵されており、室内スイッチの0N/OFFによって連動して 運転する。ファン停止時に外気の流入を防ぐ逆流弁は備わってお らず、ファンの運転を行わない条件で計測を行った。チムニー開口 部閉鎖、研究室内空気擋汼の条件での換気回数は、目貼り閉鎖なしの 0.52 回 $/ \mathrm{h}$ に対し、目貼り閉鎖をすると0.39回/hであり、24時間換気 扇を介して内外の空気の出入りが発生していることが分かった。

\section{5. まとめ}

階段室型チムニーを備え自然換気を積極的に導入した学校建築での 冬期における調查結果から、チムニー開放時と閉鎖時の熱環境および 居住者評価を把握した。また、冬期の熱環境を左右する要因について 考察した。

(1) 1） 暖房時の、床面から高さ $100 \mathrm{~mm}$ と $1100 \mathrm{~mm}$ との上下温度差は $5 \sim 7^{\circ} \mathrm{C}$ で開放時閉鎖時ともに同程度であり、チムニーの開放、閉鎖の 違いが上下温度差解消に結びつかないことが判明した。

2）開放、閉鎖時とも階段室温度は廊下温度よりも低く、開放時は 外気温と同等の時間があった。閉鎖時は廊下と階段室温度は 外気温より高めで推移し、外気流入の減少によると判断できる。 3）研究室内の廊下側と空側の温度変化の相違、上下温度分布の変 化より、開放時、閉鎖時を問わず夜中から朝方にかけて空側で コールドドラフト現象を確認した。

4）トレーサガスによる換気回数測定の結果、室内空気摚汼条件で、 開放時 0.72 回 $/ \mathrm{h}$ 、閉鎖時 0.52 回 $/ \mathrm{h}$ 、閉鎖かつ 24 時間換気扇目貼 閉鎖時0.39回/hであった。研究室内の暖気を保持するためにチム ニー開口部の閉鎖に加え、24時間換気扇の閉鎖が有効であると 判断できる。

研究室の熱環境について、チムニー開閉が上下温度差に与える影響 が見られなかった。また、チムニー閉鎖により換気回数が低下寸るこ とを確認した一方、大型ガラス空によるコールドドラフト現象や、 24 時間換気扇経由の内外空気の出入り等、チムニー開閉以外の影響を確 認した。

本研究では、中間期の自然換気を重視して設計された建物における、 自然換気を行わず機械換気を行う冬期の、チムニー開口部の開放およ び閉鎖時の室内熱環境のデータを収集し検討を行った。これら検討結 果は、今後ますます計画されるであろう自然換気利用建物の設計プロ セスにおいて、冬期の室内熱環境計画上の検討事項、例えば、大型ガ ラス空からのコールドドラフト対策としてのペアガラスの採用、24時 間換気扇からの漏気対策としての外気流入遮断ダンパーの採用、廊下 と研究室間のサッシの高気密化、などの重要性を示すものと考えられ る。 


\section{謝辞}

現地調査にご協力頂いた高松大学の関係各位に深く感謝いたします。 3 章の 1 年目調査について、調查結果は当時大阪大学大学院生であった 若松夏加氏が取りまとめられたものを引用させて頂き、調査実施にお いては当時大阪大学大学院生であった藤本徹氏ならびに竹中工務店技 術研究所の田中規敏氏にご協力頂きました。今回調查では、大阪大学 大学院生の姜丞氏之、竹中工務店技術研究所の和田一樹氏にご助力を 頂きました。あわせてこの場をお借りしてお礼申し上げます。

\section{本論文に関連した既発表論文等}

(1) 藤本徹, 津村勇次, 若松夏加, 甲谷寿史, 相良和伸, 山中俊夫, 桃井良尚, 坂口武司, 田中規敏 : 階段室型チムニーが設置された学校建築の自然換気 に関する研究 (その1〜3), 日本建築学会近畿支部研究報告集 第49号, 環境系，pp. 73-84，2009年6月

（2）藤本徹, 津村勇次, 若松夏加, 甲谷寿史, 相良和伸, 山中俊夫, 桃井良尚, 坂口武司，田中規敏：階段室型チムニーが設置された学校建築の自然換気 に関する研究 (その4 6)，日本建築学会大会学術講演梗概集 D-2, 第 49 号 pp. 761-766, 2009年8月

（3）坂口武司, 酒井利行, 増田俊哉, 萩平隆司, 樋口祥明, 高橋幹雄, 田中 規敏, 山中俊夫, 甲谷寿史, 桃井良尚 : 高松大学新校舎棟, 日本建築学会 建築デザイン発表会梗概集，pp. 52-53，2009年8月

（4）上恭子，甲谷寿史，相良和伸，山中俊夫，桃井良尚，坂口武司， 田中規敏：階段室型チムニーが設置された学校建築の自然換気に関する 研究(その7), 日本建築学会近畿支部研究報告集 第50号, 環境系, pp. 229-232，2010年6月

（5）上恭子，藤本徹，甲谷寿史，相良和伸，山中俊夫，桃井良尚，坂口武司， 田中規敏 : 階段室型チムニーが設置された学校建築の自然換気に関する 研究 (その8９），日本建築学会大会学術講演梗概集，2010年9月

（6）若松夏加，甲谷寿史，相良和伸，山中俊夫，桃井良尚，藤本徹，坂口武司， 田中規敏 : 階段室型チムニーを有する学校建築の自然換気に関する研究 (その5) 冬期における温熱環境および居住者評価, 空気調和・衛生工学会 学術講演会講演論文集，pp. 285-288，2009年9月

（7）日本建築学会：実務者のための自然換気設計ハンドブック，技報堂出版, 2013年9月

（8）増田俊哉，坂口武司，萩平隆司，田中規敏，山中俊夫，甲谷寿史，桃井 良尚：高松大学 2 号館における自然換気の計画・運用・改善, 空気調和・ 衛生工学Vol. 85 no. 7, pp. 534-535，2011年7月

\section{参考文献}

1）文部科学省：エコスクール -環境を考慮した学校施設の整備推進一, 2012.6

2）小松由佳, 相良和伸, 山中俊夫, 甲谷寿史, LIM Eunsu, 樋口祥明, 西田 恵 : 建物屋上に設置した自然換気用チムニーの換気性能に関する検討 (その1) 風圧保数を利用した換気量計算, 日本建築学会近畿支部研究 報告集，第47号，環境系 pp. 209-212，2007.6

3）山本佳嗣，久保木真俊，鈴木宏昌，田辺新一：自然換気システムの運用 実態に関する調査，日本建築学会環境系論文集 第619号，pp. 9-16, 2007. 9

4） SHASE-S 116-2011 トレーサガスを用いた単室の換気量測定法、空気調和 ・衛生工学会規格, 2011

5）山本佳嗣，田辺新一：自然換気の使いこなし術，オーム社「設備と管理」 2013. 2, pp. 57-66

6）金政秀，川口知真，田辺新一: 執務者による自然換気空の開閉行為に関寸 る研究，日本建築学会環境系論文集 第643号，pp. 1075-1082，2009.9

7）鍋谷めぐみ，田中規敏，山中俊夫，甲谷寿史，桃井良尚：神戸薬科大学に おける自然換気システムの計画と実施，空気調和・衛生工学Vol. 84 no. 7, pp576-577, 2010.7

8）鍋島佑基，宋城基 : 模型実験とCFDシミュレーションによるソーラーチム ニ一の最適な形状に関する検討，空気調和・衛生工学会論文集 No. 156, pp. 11-18, 2010. 3
9）品田宣輝，木村建一：ソーラーチムニーと地中ピットとを組み合わせた 自然換気システムの基本性能に関する実測調查，日本建築学会環境系 論文集 第74巻 第636号, pp169-175，2009.2

10）品田宣輝, 木村建一, 桂木宏昌, 宋城基 : ソーラーチムニーと地中ピット とを組み合わせた自然換気システムの性能に関する4年間の実測調查, 空気調和・衛生工学会論文集 No. 153, pp. 45-56, 2009. 12

11）前坂彰子, 早川眞, 吉原和正, 樋渡潔, 永田修三 : 大学校舎のソーラー チムニーの換気性能評価と設計法に関する研究，日本建築学会技術報告集 第13巻 第26号，pp. 623-628，2007. 12

12）前坂彰子, 早川眞, 吉原和正, 樋渡潔, 永田修三 : ソーラーチムニーを主 体とする環境配慮型大学校舎の自然換気に関する研究, その 4 . 中間期、 冬期の自然換気量の測定と評価, 日本建築学会大会学術講演梗概集, D-2, pp. 607-608, 2006. 9

13）吉原和正，早川眞，大野二郎，佐藤昌之，永田修三，上野祐行：ソーラー チムニーを主体とする環境配慮型大学校舎の自然換気に関する研究, その1 環境配慮型大学校舎の省エネルギー計画の概要, 日本建築学会 大会学術講演梗概集，D-2，pp. 593-594，2005.9

14）樋渡潔，早川眞，吉原和正，永田修三，上野祐行，前坂彰子：ソーラー チムニーを主体とする環境配慮型大学校舎の自然換気に関する研究, その2 測定方法及びトレーサーガスによる換気量、換気経路の把握, 日本建築学会大会学術講演梗概集，D-2，pp. 595-596，2005.9

15）前坂彰子, 早川眞, 吉原和正, 樋渡潔, 永田修三, 上野祐行 : ソーラー チムニーを主体とする環境配慮型大学校舎の自然換気に関する研究, その3 トレーサーガスを用いた換気量評価と省エネルギー効果, 日本建築学会大会学術講演梗概集，D-2，pp. 597-598，2005.9

16）阿部佑平, 菊田弘輝, 羽山広文, 繪内正道, 今井綾子, 丹保洋人, 畑中 壮大：エコスクールにおける温熱・空気環境の現状把握に関する研究, その5 冬期における自然換気性状の把握, 日本建築学会北海道支部研究 報告集，No. 82，pp. 279-282，2009.7

\section{備考}

[1] アンケート用紙は、封筒に「お願い書」を貼付け配布した。「お願い書」 中に記載がある、回答者に心理的効果をもたらしたと推測する文言は以下 の通り

「自然換気を促進するウインドチムニーを採用した 2 号館の、冬季における 居住者意識調査と温熱環境測定を行います。冬季に建物内に冷気が入り 暖気が階段室トップガラリから逃げる現象を低減するための閉鎖扉を計画 しており、(以下略)」 